\title{
Implementasi Koordinat Google dan Citra Kamera Pada Aplikasi Monitoring Petugas Berbasis Android
}

\author{
Bayu Priyatna ${ }^{1}$ \\ Fitria Nurapriani ${ }^{2}$ \\ bayu.priyatna@ubpkarawang.ac.id ${ }^{1}$ \\ fitria.nurapriani@ubpkarawang.ac.id ${ }^{2}$ \\ Universitas Buana Perjuangan Karawang
}

\begin{abstract}
The development of technology is currently so fast, the use of various fields, especially in telecommunications, is now increasingly being improved and developed, such as the internet network, which has now reached the fourth generation or $4 G$, now a new technology has emerged, namely 5G. In addition to the internet, some technologies are widely developed by Google, where Google is a United States company engaged in services, with its flagship product being the Web Browser, Google Map which is now in great demand by the public to find information, in addition to web browsers and google maps. Many other technologies are beneficial for software developers and the general public. The Android operating system currently dominates the market as an Open Sources platform used for making mobile-based applications by developers, ranging from games, e-learning, ebooks, e-commerce and so on both free and paid, DISKOMINFO which regulates all systems spread across the entire Bekasi district, but currently the problems faced by KOMINFO Bekasi are; The points of location for the distribution of consumers are not mapped so that the division of the area is difficult to determine, field officers, visit not on time and so on. The method in this research is using UCD. The test results using alpha testing from the field officer data showed that $79.62 \%$ strongly agreed, 9.26\% agreed, and the rest disagreed. Most of the officers agreed with the system that had been made, and only a few officers disagreed with the application. From the admin officers and finance data, it shows that $90.44 \%$ strongly agree, $1.55 \%$ agree, and the rest disagree. It can be concluded that the monitoring system that has been created is easy and feasible to use.
\end{abstract}

Keywords: Google, DISKOMINFO, Monitoring, Alpha testing, Bekasi. 


\begin{abstract}
ABSTRAK
Perkembangan Teknologi sekarang ini semaking cepat, pemanfaattan diberbagai bidang terutama pada telekomunikasi kini semakin terus diperbaiki dan dikembangkan sepertihannya jaringan internet yang kini sudah sampai kepada generasi ke empat atau 4G bakan kini sudah muncul teknologi baru yaitu 5G. Selain internet tedapat juga teknologi yang banyak dikembangkan oleh Google, dimana google merupakan perusahaan Amerika serikat yang bergerak dibidang jasa atau Service, dengan produk andalannya adalah Web Browser, Google Map yang kini banyak diminati oleh kalangan masyarakat untuk mencari informasi, selain web browser dan google map masih banyak teknologi lainnya yang sangat berguna bagi pengembang software maupun masyarakat umum. Android sistem operasi yang saat ini mendominasi pasar sebagai platform Open Sources yang digunakan untuk pembuatan aplikasi berbasis mobile oleh para pengembang, mulai dari games, e-learning, ebook, ecommerce dan lain sebagainya baik gratis maupun berbayar, DISKOMINFO yang mengatur seluruh sistem yang tersebar di seluruh wilayah kabupaten Bekasi, namun saat ini prmasalahan yang dihadapi KOMINFO Bekasi adalah; Titik-titik lokasi penyebaran konsumen tidak di petakan sehingga pembagian wilayah sulit untuk ditetapkan, Kunjungan petugas lapangan tidak tepat waktu dan lain sebagainya. Metode dalam pengembangan ini menggunakan UCD. Hasil pengujian menggunakan alpha testing dari data petugas lapangan menunjukan bahwa 79,62\% menyatakan sangat setuju, 9,26\% menyatakan setuju dan sisanya menyatakan tidak setuju. Sebagian banyak petugas setuju dengan sistem yang telah dibuat dan hanya sedikit petugas yang tidak setuju dengan aplikasi tersebut. Dari data admin petugas dan keuangan menunjukan bahwa 90,44\% menyatakan sangat setuju, 1,55\% menyatakan setuju dan sisanya menyatakan tidak setuju. Dapat disimpulkan bahwa sistem monitoring yang telah dibuat mudah dan layak untuk digunakan.
\end{abstract}

Kata Kunci: Google, DISKOMINFO, Monitoring, Alpha testing, Bekasi.

\title{
PENDAHULUAN
}

Perkembangan Teknologi sekarang ini semaking cepat, pemanfaattan diberbagai bidang terutama pada telekomunikasi kini semakin terus diperbaiki dan dikembangkan sepertihannya jaringan internet yang kini sudah sampai kepada generasi ke empat atau 4G bakan kini sudah muncul teknologi baru yaitu 5G. Selain internet tedapat juga teknologi yang banyak 
dikembangkan oleh Google, dimana google merupakan perusahaan Amerika serikat yang bergerak dibidang jasa atau Service, dengan produk andalannya adalah Web Browser, Google Map yang kini banyak diminati oleh kalangan masyarakat untuk mencari informasi, selain web browser dan google map masih banyak teknologi lainnya yang sangat berguna bagi pengembang software maupun masyarakat umum. [1].

Android sistem operasi yang saat ini mendominasi pasar sebagai platform Open Sources yang digunakan untuk pembuatan aplikasi berbasis mobile oleh para pengembang, mulai dari games, e-learning, ebook, ecommerce dan lain sebagainya baik gratis maupun berbayar [2]. Penggunaan android sekarang ini menjadi kebutuhan utama yang harus dipenuhi agar dapat menunjang kegiatan baik formal maupun non formali. Hampir seluruh fasilitas dari google diimplementasikan pada platform android kususnya aplikasi-aplikasi penunjang kebutuhan dalam bekerja seperti: Google Office, Google Drive, Gmail, Google Class Room, Google Map dan masih banyak yang lainnya.

Monitoring adalah kegiatan untuk melihat proses yang sedang/belum dilakukan. Dengan adanya monitoring dapat memantau aktivitas atau kegiatan yang dilakukan oleh user/program apakah berjalan sesuai atau kurang sesuai dengan yang di harapan [3].

Pada Pemerintah Kabupaten Bekasi Provinsi Jawabarat mengelola fasilitas jaringan yang yang sengaja diarahkan keberbagai tempat mulai dari sekolah-sekolah sampai dengan perkantoran yang terletak pada wilayah pemerintah Bekasi, pengelolaan tersebut mengakibatkan kompeksitas tersendiri saat melakukan perawatan dan perbaikan terhadap perangkat jaringan di tempat tersebut. Pemerintah Kabupaten Bekasi membentuk tim khusus yang dibuat oleh DISKOMINFO (Dinas Kementerian Komunikasi dan Informatika) Kabupaten Bekasi untuk monitoring seluruh perangkat jaringan internet yang terhubung. Secara teknis monitoring yang dilakukan yaitu petugas mengunjungi secara personal ke-tempat-tempat saat terjadi masalah internet dengan tujuan tim petugas lapangan dapat mengatasi masalah di tempat tersebut.

Berdasarkan hasil dari wawancara kepada DISKOMINFO Bekasi dan Staff IT. Kegiatan monitoring saat ini masih belum efektif, dikarenakan: 1. Titik-titik lokasi penyebaran konsumen tidak di petakan sehingga pembagian wilayah sulit untuk ditetapkan, 2. Kunjungan petugas lapangan tidak tepat waktu, mengakibatkan permasalahan pada jaringan tidak cepat untuk tangani, 2. Manipulasi data Kunjungan oleh petugas lapangan. 3. Mengerjakan pekerjaan dengan waktu yang lama sedangkan permasalahan tidak begitu sulit sehingga oknum petugas meminta bayaran lebih. 
Dari uraian permasalahan tersebut maka perlu adanya pembuatan sistem ninformasi yang mampu memonitoring petugas jaringan, sehingga setiap kegiatan monitoring menjadi terpantau dan lebih efektif.

\section{METODE PENELITIAN}

\section{A. Model Rpid Aplication Development (RAD)}

Pada gambar 1 merupakan siklus dari RAD:

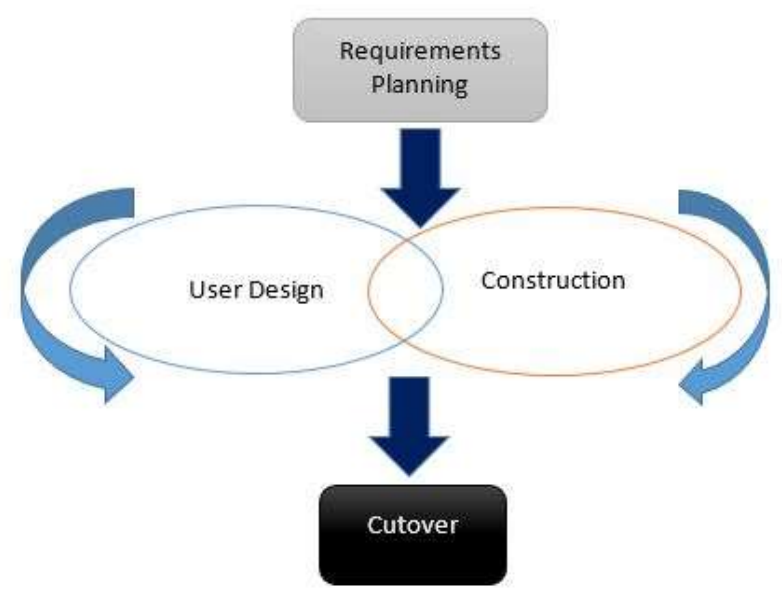

Gambar 1. Metode rapid application development (RAD) ${ }^{[12]}$

Empat fase utama RAD dapat dibagi menjadi beberapa fase yang lebih spesifik seperti yang digambarkan dalam Gambar 1. Tujuan umum dari pemecahan fase adalah untuk memberikan informasi langkah demi langkah bagi pengembang yang akan mencoba menggunakan model RAD untuk membangun perangkat lunak. Seperti yang terlihat pada gambar, ada 2 loop jikakondisional, setiap loop menunjukkan seberapa kuat keterlibatan pengguna dalam model. Misalnya, loop pertama ditampilkan bahwa tahap perencanaan persyaratan tidak akan maju ke fase berikutnya ketika informasi tentang persyaratan sistem tidak lengkap dan kelengkapan informasi diputuskan oleh pengguna. Rincian tentang setiap fase utama RAD dan hasil pada setiap fase akan dijelaskan pada bagian selanjutnya

\section{B. Model Pengembangan Sistem}

Penelitian ini menggunakan model pengembangan sistem RAD (Model Rpid Aplication Development), Metode Rapid Application Development (RAD) sebagaimana dinyatakan oleh James Martin erdiri dari empat fase: fase perencanaan persyaratan, fase desain pengguna, fase 
konstruksi, dan fase cutover. Setiap fase akan dilaksanakan secara berurutan untuk mengembangkan CLIS, dimulai dari tahap perencanaan persyaratan dan berakhir dengan fase cutover [11], [12]. Berikut pada gambar 3 merupagan flowgraf metodologi dan pengembangan sistem pada penelitian ini:

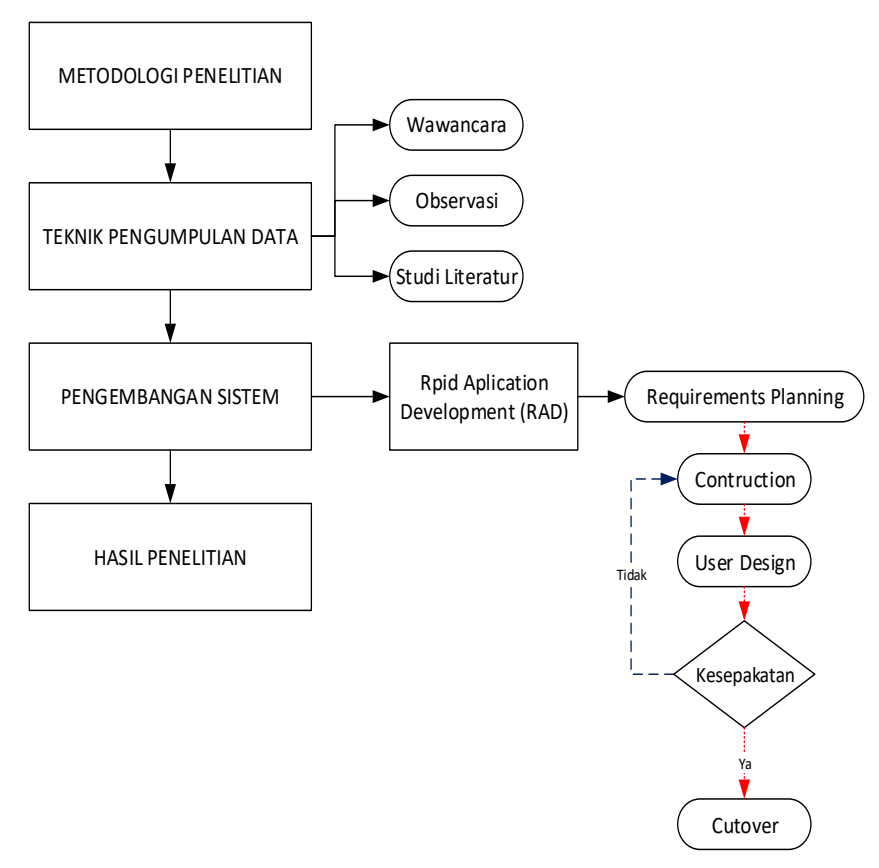

Gambar 3. Metodologi dan model pengembangan sistem

\section{Teknik Pengumpulan Data}

Dalam megumpulkan data peneliti menggunakan beberapa metode antara lain:

a. Metode observasi.

Metode ini digunakan untuk mendapatkan informasi dengan mengadakan pengamatan dan pencatatan secara teliti tentang sistem monitoring yang sedang berjalan.

b. Metode Wawancara

Metode pengumpulan data melalui pengamatan dengan melakukan tanya jawab yang dilakukan secara lisan kepada pemrintah kabupaten Bekasi.

c. Studi Literatur

mengenai hal-hal atau variabel-variabel yang berupa jurnal ilmiah, buku, modul workshop, catatan, transkrip, buku, surat kabar, majalah, notulen, rapat, agenda dan sebagainya.

2. Analisa Data dan Testing 
Analisis data pada penelitian ini menggunakan teknik deskriptif kuantitatif yang menggambarkan sistem monitoring.

\section{PEMBAHASAN}

Dari analisis kebutuhan sistem berdasarkan wawancara, observasi, studi literatur dan juga hasil dari kesepakatan stakeholder dihasilkan suatu rancangan sistem yang dibuat kedalam bentuk use case, activity dan class diagram:

\section{A. Perancangan Sistem Baru}

\section{Use Case Diagram Sistem Monitoring}

Pada rancangan sistem baru ini dibuat atau dituangkan kedalam use case diagram untuk mengetahui aktor-aktor yang terlibat dengan sistem, Gambar 4 adalah use case diagram monitoring:

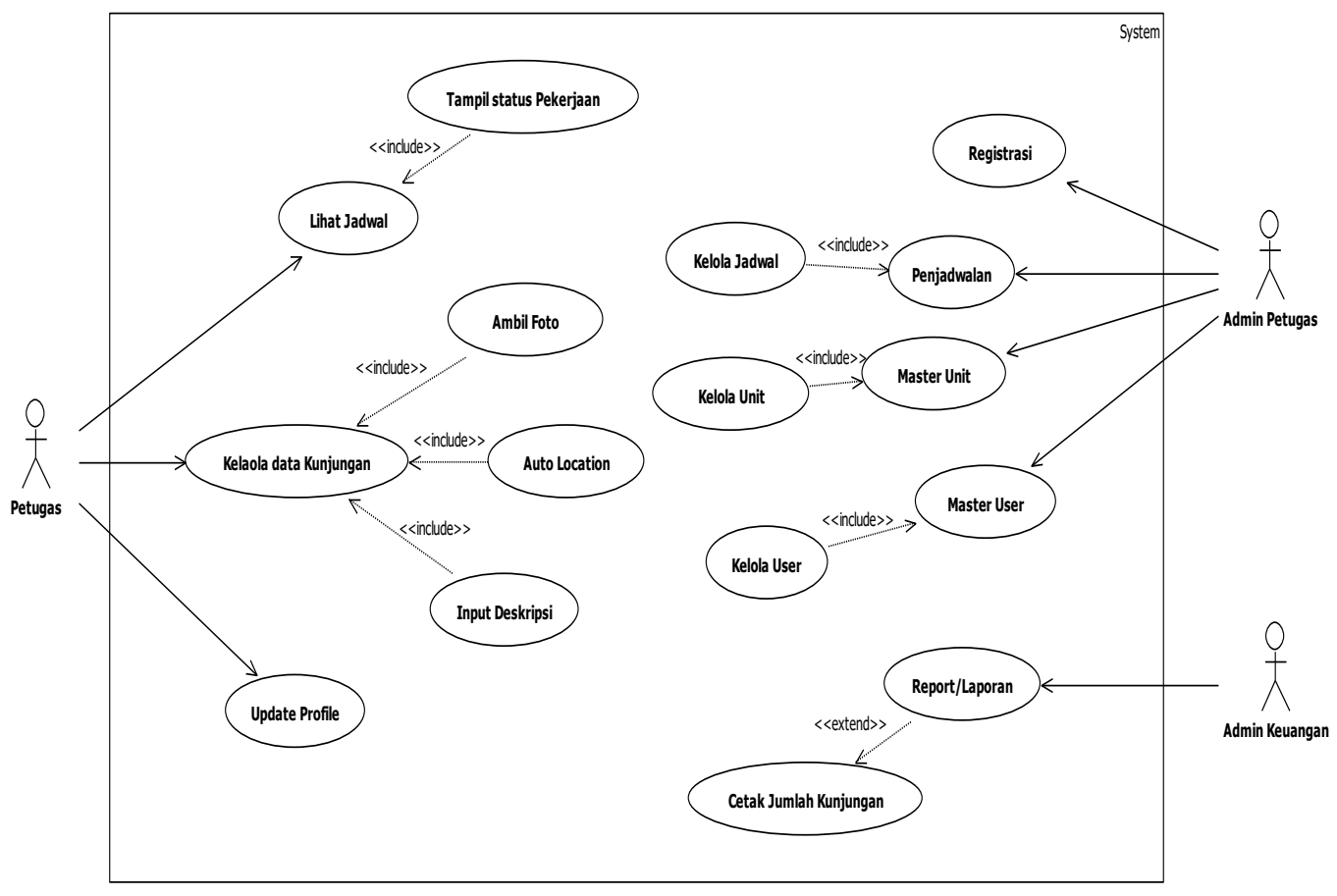

Gambar 4. Use case diagram monitoring

Pada gambar 4 menggambarkan terdapat 3 aktor yaitu; petugas, dimana petugas ini dapat mengakses kelola data profil, melihat jadwal dan mengelola data kunjungan, berikutnya Admnin petugas dapat mengakses, master unit, penjadwalan, registrasi dan master user termasuk mengatur lokasi atau area-area yang menjadi tanggungjawab petugas dengan 
melakukan pemetaan, dan yang terakhir Admin keuangan mencetak hasil dari laporan kunjungan petugas.

\section{B. Activity Diagram}

Pada activity diagram ini menggambarkan interaksi aktor denga sistem seperti yang digambarkan pada Use case diagram sistem monitoring. Gambar 5,6,7,8 dan 9 menggambarkan masing-masing aktifitas pada sistem monitoring:

\section{Activity Diagram Petugas}

Petugas yang dimaksud pada aktivity diagram disini adalah petugas lapangan yang mana sebagai ujung tombak pelaksanaan monitoring. Berikut pada gambar 5 adalah Activity diagram Petugas:

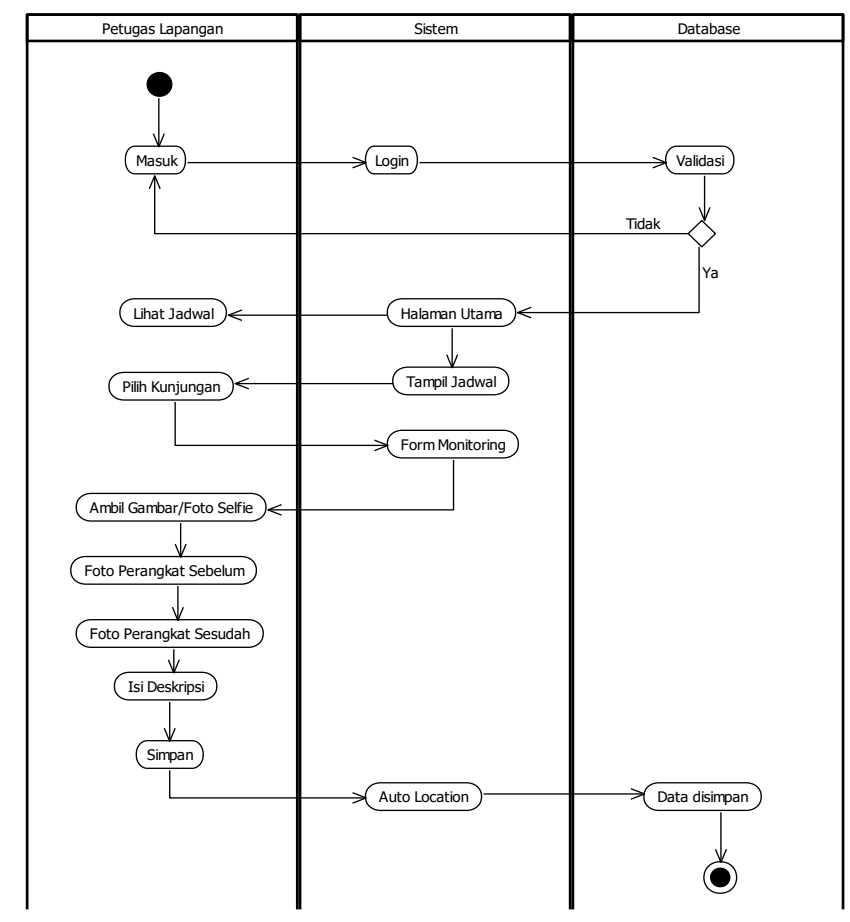

Gambar 5. Activity diagram petugas lapangan

\section{Activity Diagram Admin Petugas}

Admin Petugas yang dimaksud pada aktivity diagram disini adalah administrator yang mengatur petugas lapangan yang mana sebagai manajemen pelaksanaan monitoring. Berikut pada gambar 6 adalah Activity diagram Admin Petugas: 
Bayu Priyatna, Fitria Nurapriani

Vol 5 No 1

ISSN : 2541-6995

E ISSN : 2580-5517

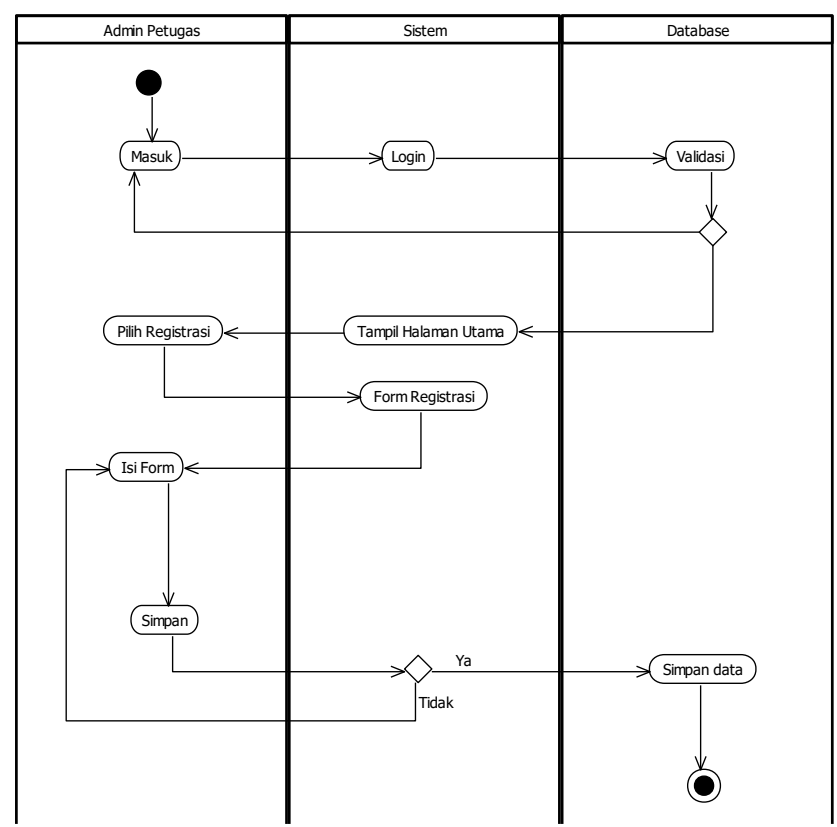

Gambar 6. Activity diagram registrasi

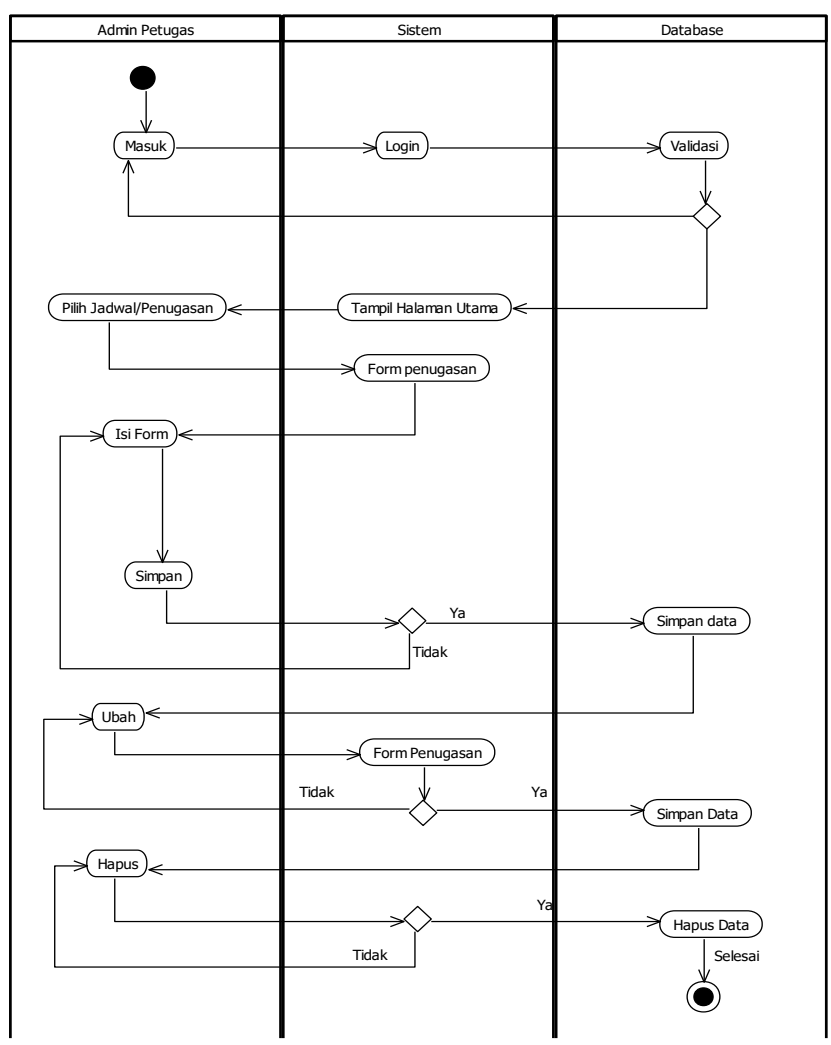

Gambar 7. Activity diagram penjadwalan petugas 
Bayu Priyatna, Fitria Nurapriani

Vol 5 No 1

ISSN : 2541-6995

E ISSN : 2580-5517

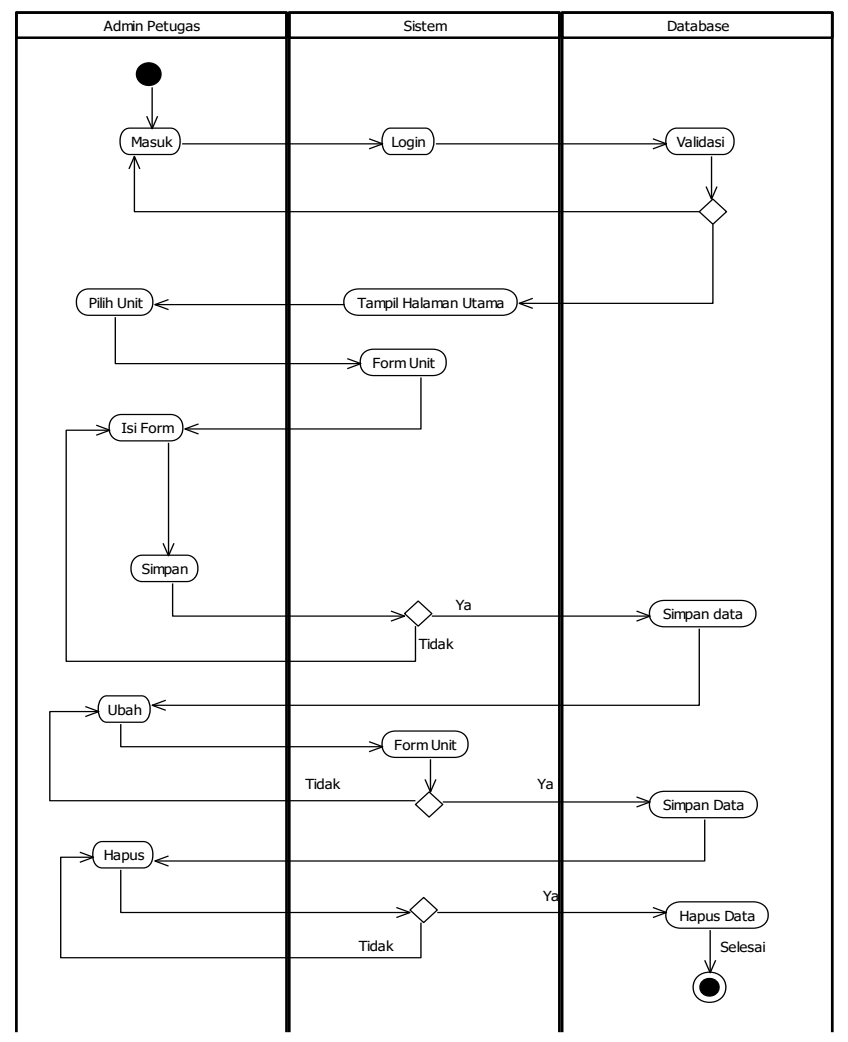

Gambar 8. Activity diagram unit lokasi

3. Activity Diagram Admin Keuangan

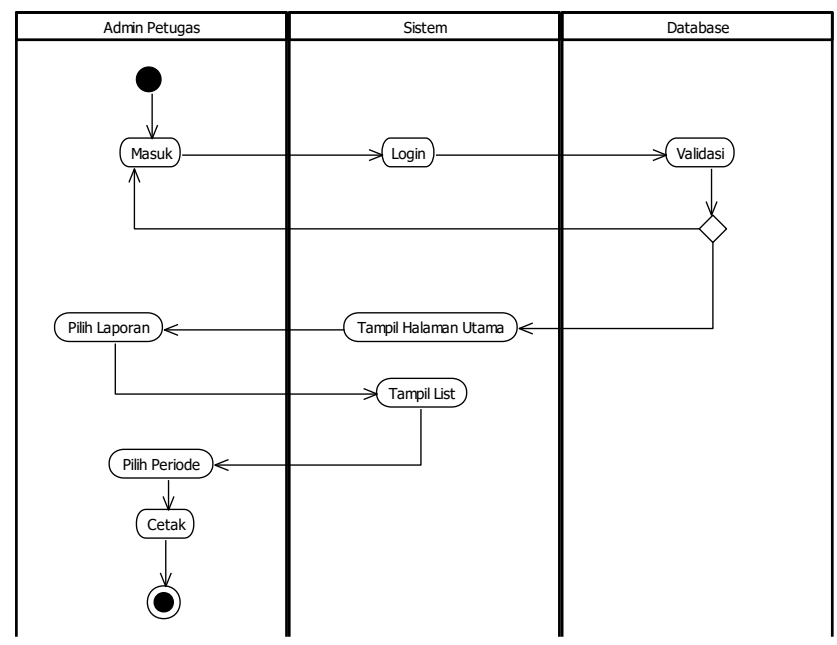

Gambar 9. Activity diagram laporan keuangan 


\section{Perancangan Database}

Perancangan database yang dimaksud pada class diagram disini adalah hubungan antara tabel-tabel yang yang terkait dalam menunjang sistem monitoring. Berikut pada gambar 10 adalah gambar class diagram sistem monitoring:

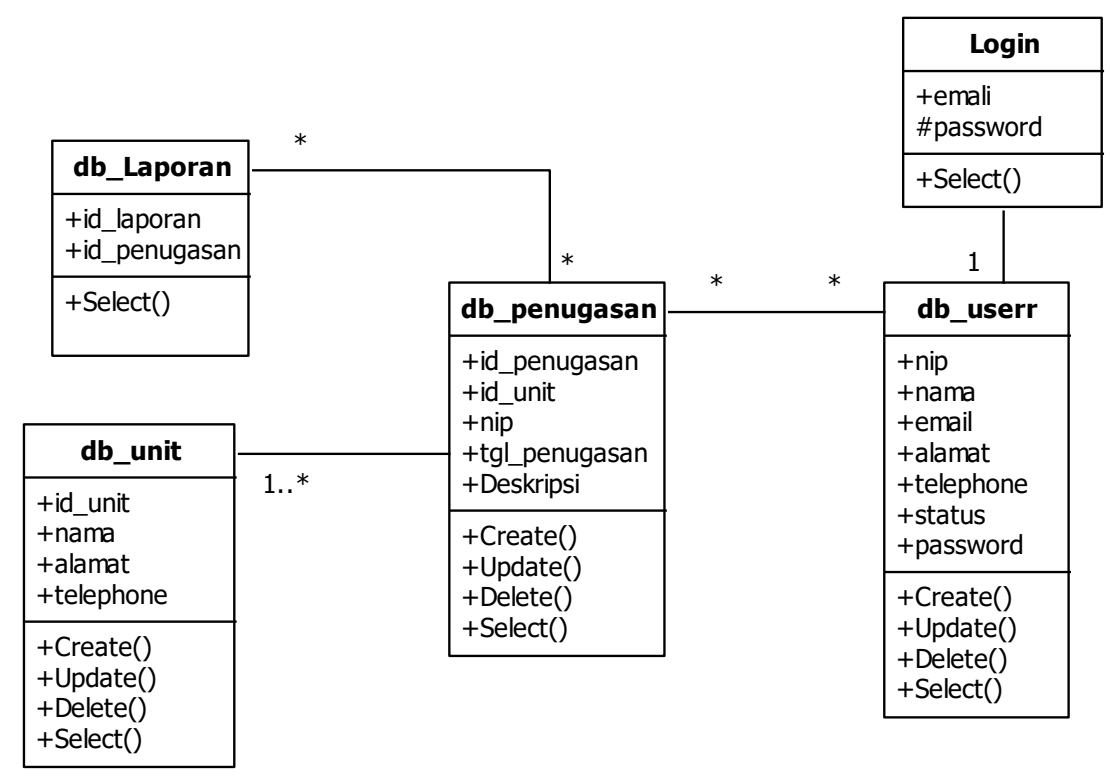

Gambar 10. Class diagram perancangan database monitoring

\section{Pengkodean Sistem}

Hasil Perancangan sistem yang sudah dibuat kemudian di implementasikan kedalam bentuk kode program atau bahasa pemrograman. Berikut pada gambar 11, 12, 13, 14 dan 15 adalah gambar hasil pengkodean sistem monitoring: 
1. Interface Sistem Monitoring Petugas Lapangan
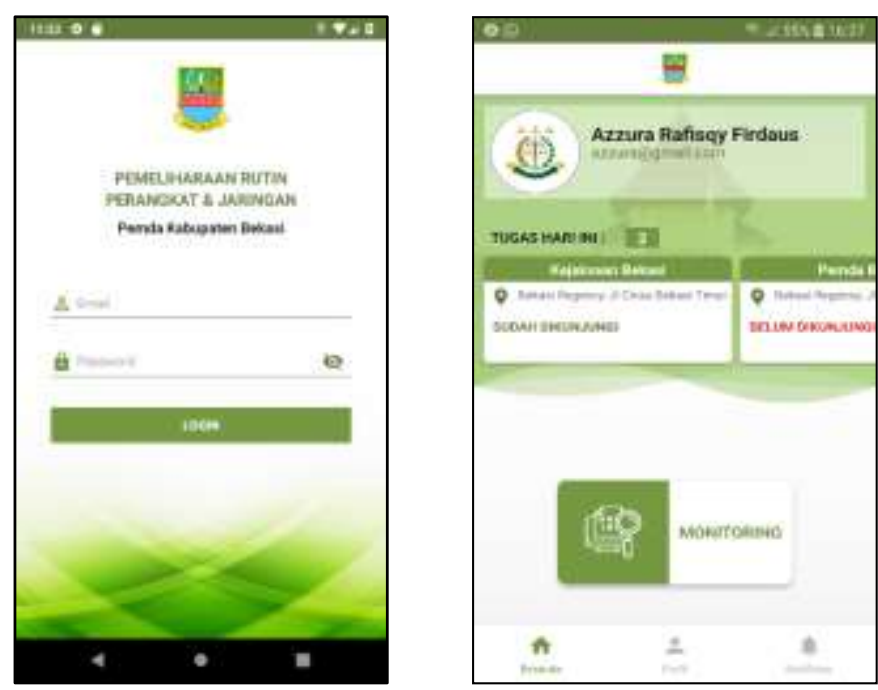

Gambar 11. Login petugas lapangan dan halaman utama sistem monitoring
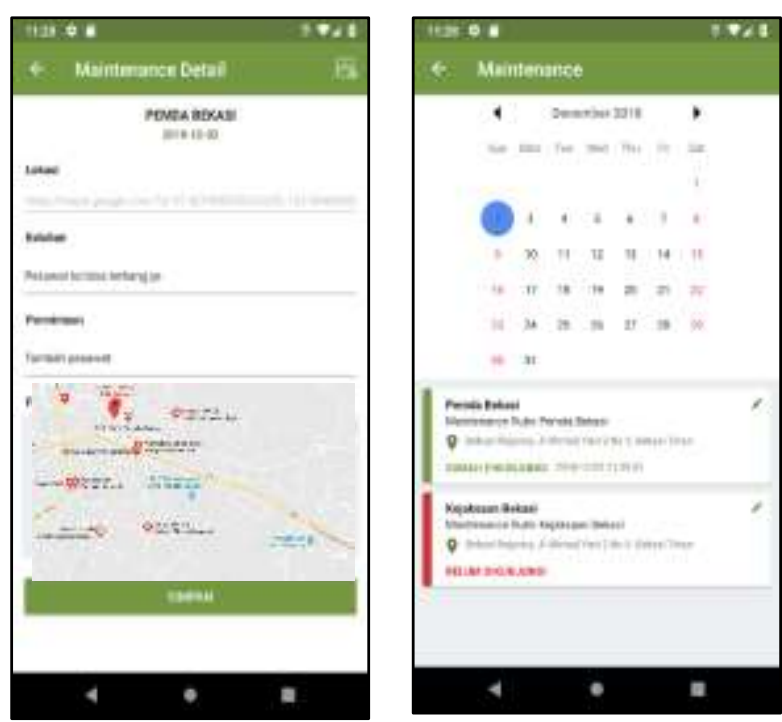

Gambar 12. Jadwal petugas lapangan dan form monitoring

2. Interface Sistem Monitoring Admin Petugas 


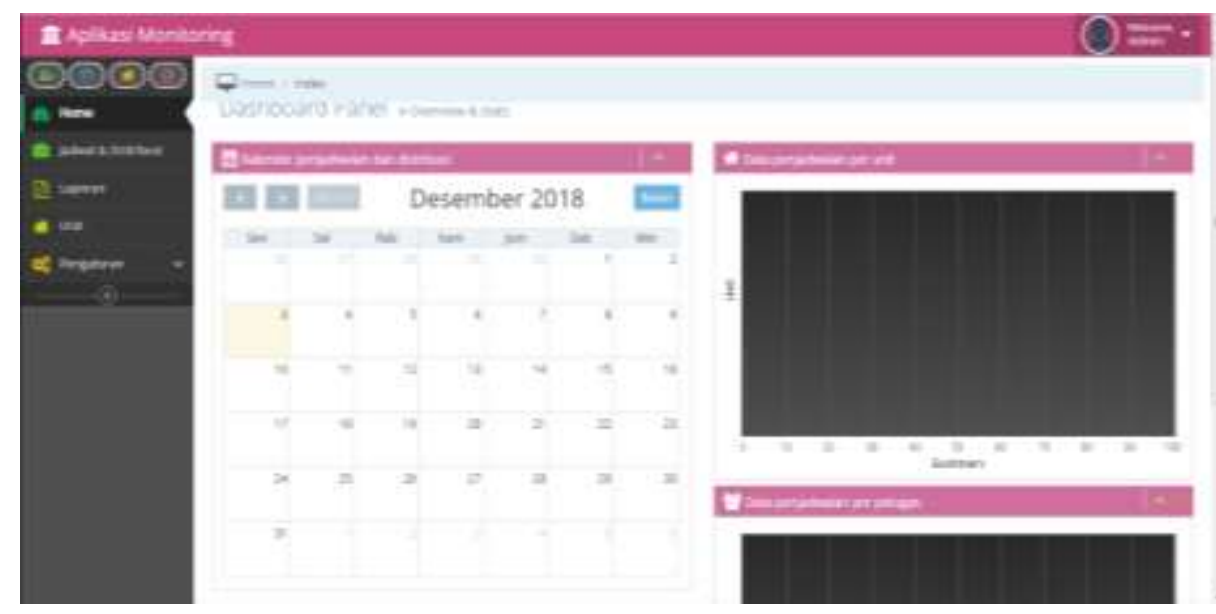

Gambar 13. Penugasan pegawai lapangan

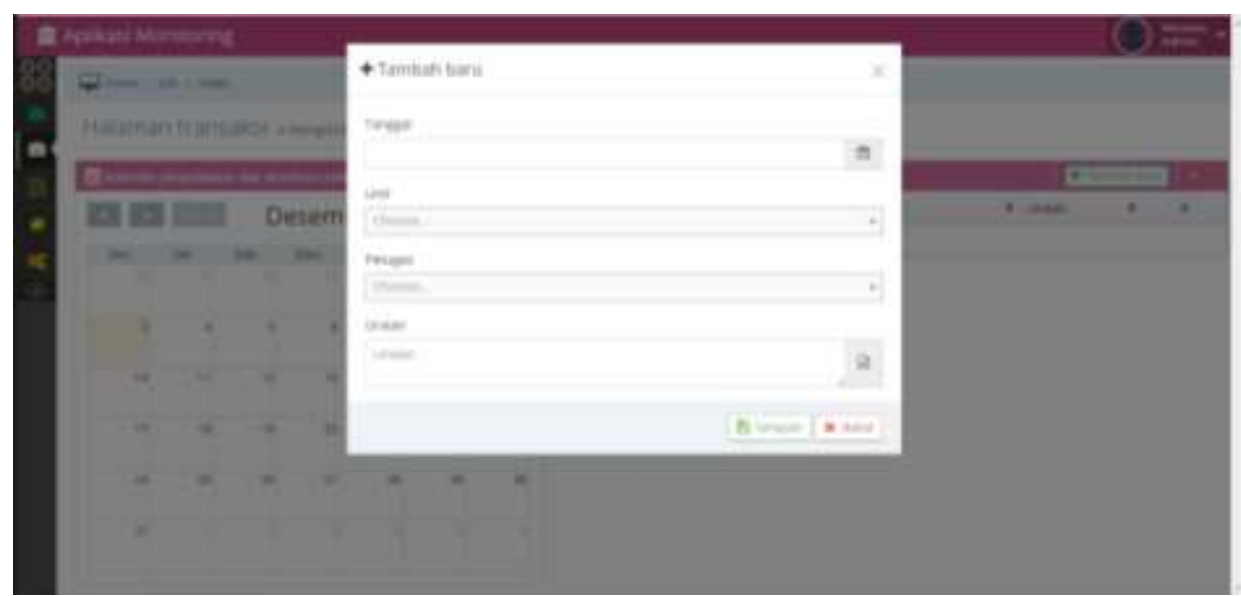

Gambar 14. Form tambah penugasan pegawai lapangan

\section{Interface Sistem Monitoring Admin Keuangan}

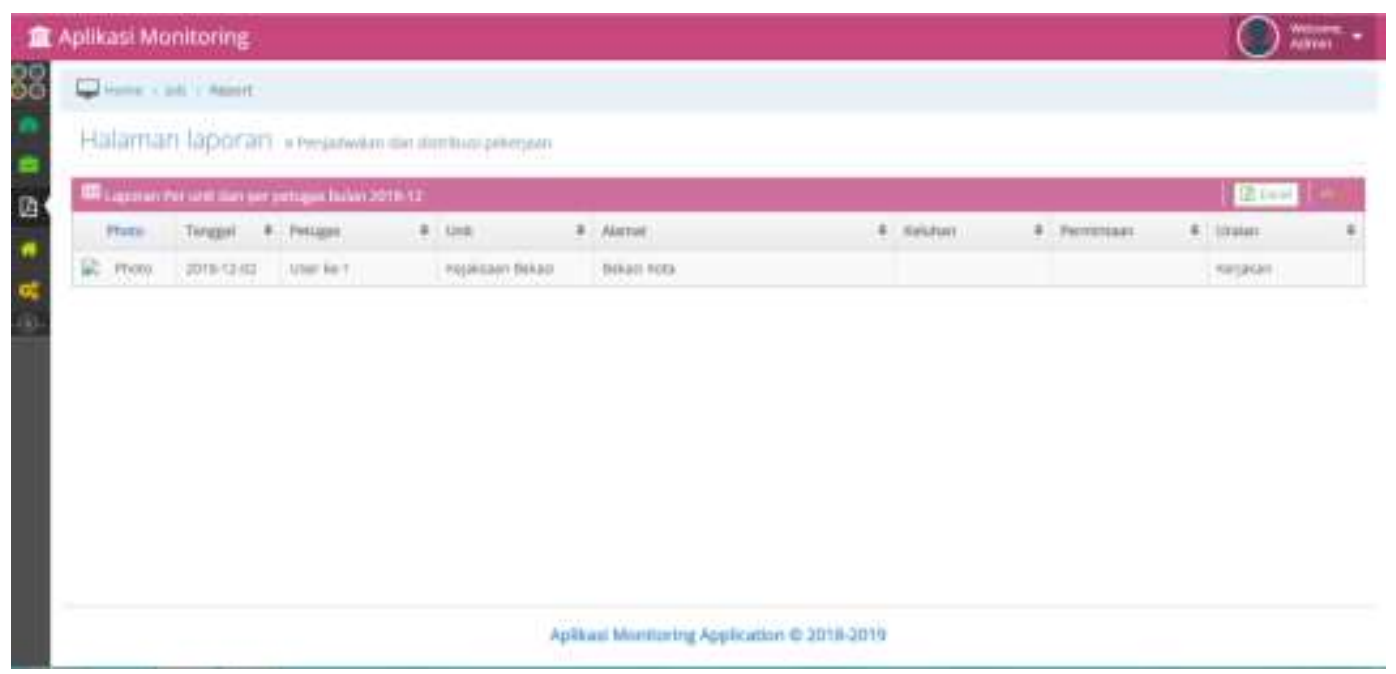

Gambar 15. Laporan hasil penugasan pegawai lapangan 


\section{E. Pengujian Sistem}

Pengujian sistem dengan metode alpha testing dilakukan oleh peneliti dimaksudkan untuk menilai kinerja dari software/sistem monitoring baik dari sisi petugas lapangan, admin petugas lapaangan dan admin keuangan. Penilayan dilakukan setelah masing-masing petugas mengisi form kuesioner. Adapun berikut ini rumus perhitungan yang digunakan:

$$
\frac{k}{j} x 100
$$

1. Keterangan :

2. $\mathrm{k}=$ Total masing-masing jawaban dari tabel kemudahan sistem ditambah tabel keakuratan sistem

3. $\mathrm{j}=$ Total keseluruhan jawaban dari tabel kemudahan sistem ditambah tabel keakuratan

Hasil dari pengujian alpha testing dapat dilihat pada tabel 1:

Tabel 1 Hasil perhitungan Alpha Testing

\begin{tabular}{|l|l|c|c|c|c|c|}
\hline \multirow{2}{*}{ No } & \multirow{2}{*}{ Kemudahan dan interface sistem } & \multicolumn{5}{|c|}{ Hasil } \\
\cline { 4 - 7 } & & SS & S & KS & TS & STS \\
\hline 1 & Petugas Lapangan & $79,62 \%$ & $9,26 \%$ & $9,02 \%$ & $2,08 \%$ & $0 \%$ \\
\hline 2 & Admin Petugas dan Keuangan & $90,44 \%$ & $1,55 \%$ & $0 \%$ & $0 \%$ & $0 \%$ \\
\hline
\end{tabular}

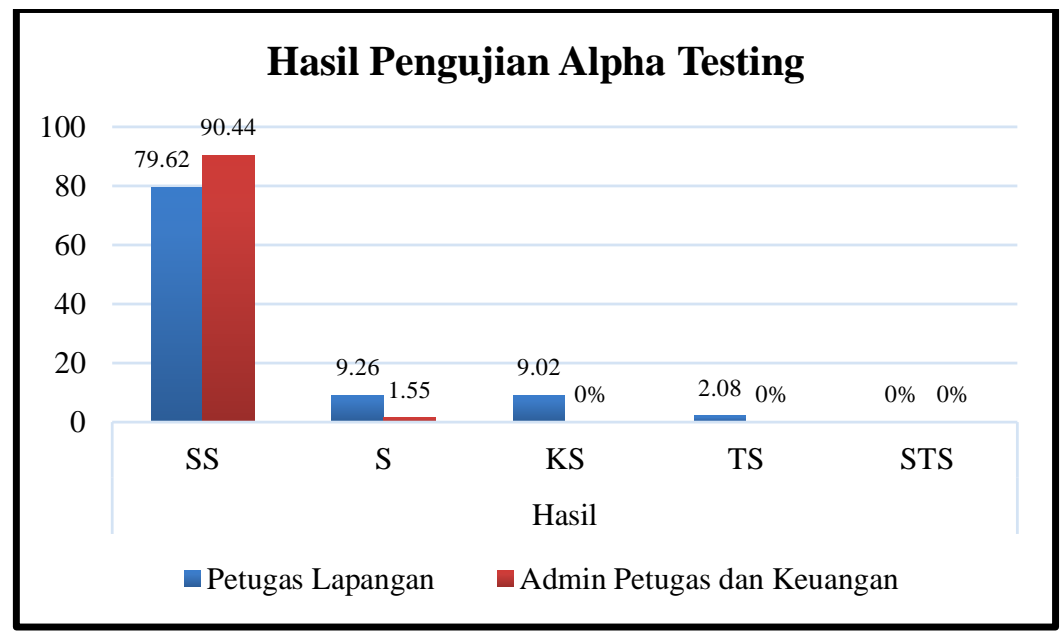

Gambar 16. Gambar grafik pengujian apha testing 


\section{KESIMPULAN}

Berdasarkan hasil dari penerapan RAD dan analisis sistem didapatkan hasil sebagai berikut: Hasil pengujian data petugas lapangan menunjukan bahwa 79,62\% menyatakan sangat setuju, 9,26\% menyatakan setuju dan sisanya menyatakan tidak setuju. Sebagian banyak petugas setuju dengan sistem yang telah dibuat dan hanya sedikit petugas yang tidak setuju dengan aplikasi tersebut. Dari data admin petugas dan keuangan menunjukan bahwa 90, 44\% menyatakan sangat setuju, 1,55\% menyatakan setuju dan sisanya menyatakan tidak setuju. Dari hasil pengujian, metode alpha testing, dapat disimpulkan bahwa sistem monitoring yang telah dibuat mudah dan layak untuk digunakan. Akan tetapi untuk mendapatkan hasil yang maksimal perlu adanya pengembangan sistem yang lebih lanjut, seperti memperbaiki akurasi maping dan penggunaan map yang open source (Openmaping).

\section{DAFTAR PUSTAKA}

[1] A. Kushwaha and V. Kushwaha, "Location Based Services using Android Mobile Operating System,” Int. J. Artif. Intell. Knowl. Discov., vol. 1, no. 1, pp. 14-20, 2011.

[2] A. Hendini, "Pemodelan UML sistem informasi Monitoring Penjualan dan stok barang," Pemodelan Uml Sist. Inf. Monit. Penjualan Dan Stok Barang (Studi Kasus Distro Zhezha Pontianak), vol. IV, no. 2, pp. 107-116, 2016.

[3] S. Lorena, B. Ginting, Y. Ahmad, and G. Saputra, "Pemanfaatan Teknologi LBS dan Penerapan Teknologi Augmented Reality Pada Pembangunan Aplikasi Denah Petunjuk Ruangan ( Studi Kasus : Unikom Bandung ) The Use of LBS Technology and The Application of Augmented Reality Technology in The Development of Room .”

[4] D. . Michael and D. Gustina, "Rancang Bangun Prototype Monitoring Kapasitas Air Pada Kolam Ikan Secara Otomatis Dengan Menggunakan Mikrokontroller Arduino,” J. IKRA-ITH Inform. Vol 3 No 2 Juli 2019 ISSN 2580-4316, vol. 3, no. 2, pp. 59-66, 2018.

[5] D. P. Buwana, S. Setiawidayat, and M. Mukhsin, "Sistem Pengendalian Lampu Penerangan Jalan Umum (PJU) Melalui Jaringan Internet Berbasis Android," JOINTECS (Journal Inf. Technol. Comput. Sci., vol. 3, no. 3, pp. 149-154, 2018.

[6] C. Framework, "Teacher Monitoring Application in Teaching Based on CodeIgniter Framework in High Schools," Buana Inf. Tchnology Comput. Sci. (BIT CS) Teach., vol. 
1 , no. 1, pp. $12-15,2020$.

[7] D. Kurniawan and B. Priyatna, "Pengamanan Data Berbasis Mobile Android Dengan Penggabungan Linear Feedback Shift Register ( Lfsr ) Dan Modifikasi Matriks,” J. Telemat. MKOM, vol. 10, no. 1, pp. 42-46, 2018.

[8] S. Samsinar and U. B. Luhur, "BARANG DENGAN METODOLOGI BERORIENTASI OBYEK STUDI KASUS : PADA PT . MOIKO TASINDO,” no. March, 2018.

[9] A. Solehudin, N. Heryana, and Y. Cahyana, "Designing and Building Client-Server Based Student Admission Applications," Buana Inf. Tchnology Comput. Sci. (BIT CS), vol. 1, no. 1, pp. 16-18, 2020.

[10] L. Apriliana, U. D. Darusalam, and N. D. Nathasia, "Clustering Server Pada Cloud Computing Berbasis Proxmox VE Menggunakan Metode High Availability," JOINTECS (Journal Inf. Technol. Comput. Sci., vol. 3, no. 1, 2018.

[11] S. Kosasi and I. D. A. E. Yuliani, "Simetris : jurnal teknik mesin, elektro dan ilmu komputer.," Simetris J. Tek. Mesin, Elektro dan Ilmu Komput., vol. 6, no. 1, pp. 27-36, 2015.

[12] T. Wahyuningrum and D. Januarita, "Perancangan Web e-Commerce dengan Metode Rapid Application Development ( RAD ) untuk Produk Unggulan Desa,” vol. 2014, no. November, pp. 81-88, 2014.

[13] S. Antonio Gusmao, Sholeh Hadi Pramono, "Sistem Informasi Geografis Pariwisata Berbasis Web Dan Pencarian Jalur Terpendek Dengan Algoritma Dijkstra,” J. Electr. Electron. Commun. Control. Informatics, Syst., vol. 7, no. 2, pp. 125-130, 2013.

[14] F. T. Industri, J. T. Informatika, and U. K. Petra, "Perencanaan Rute Perjalanan Di Jawa Timur Dengan Dukungan Gis Menggunakan Metode Dijkstra S," J. Inform., vol. 3, no. 2, pp. 63-63, 2002.

[15] A. A. Salam, "Sistem Informasi Geografis Pemetaan Aset Daerah Menggunakan Algoritma Djikstra Di BKD Kota Cirebon,” vol. 1, no. 1, pp. 1-11, 2019. 
Bayu Priyatna, Fitria Nurapriani Vol 5 No 1

ISSN : 2541-6995

E ISSN : 2580-5517

121 B u a n a $11 \mathrm{mu}$ 